University of Nebraska - Lincoln

DigitalCommons@University of Nebraska - Lincoln

Faculty Publications: Department of Entomology

Response of Lowland Rice Plants to Simulated Insect Defoliation in West Africa

I. O. Oyediran

E. A. Heinrichs

Follow this and additional works at: https://digitalcommons.unl.edu/entomologyfacpub

Part of the Agriculture Commons, Agronomy and Crop Sciences Commons, and the Entomology Commons

This Article is brought to you for free and open access by the Entomology, Department of at DigitalCommons@University of Nebraska - Lincoln. It has been accepted for inclusion in Faculty Publications: Department of Entomology by an authorized administrator of DigitalCommons@University of Nebraska - Lincoln. 


\title{
Response of Lowland Rice Plants to Simulated Insect Defoliation in West Africa
}

\author{
I. O. Oyediran and E. A. Heinrichs* \\ Department of Entomology, University of Nebraska-Lincoln, Lincoln, Nebraska, USA \\ Corresponding author - E. A. Heinrichs, email eheinrichs2@unl.edu
}

\begin{abstract}
Field experiments were conducted to investigate the impact of simulated insect-caused defoliation on irrigated rice. Defoliation levels tested were $0 \%$ (control), 25\% defoliation at 21 days after transplanting (dat), 25\% defoliation at 41 dat, 25\% defoliation at 21 and 42 dat, $50 \%$ defoliation at 21 dat, $50 \%$ defoliation at 42 dat, $75 \%$ defoliation at 21 dat, 75\% defoliation at 42 dat, $75 \%$ defoliation at 21 and 42 dat, 100\% defoliation at 21 dat, and 100\% defoliation at 21 and 42 dat. Tiller height, total number of tillers, percent panicle-bearing tillers, weight of 100 grains, and grain yields were recorded. The rice plant when defoliated just before tillering or in the tillering stage has the ability to compensate for defoliation damage. No yield losses occurred at $25 \%$ defoliation. Defoliation of $100 \%$ had a significant effect on the total number of tillers and on grain yield. Yield losses at 100\% defoliation over the 3 years of the study averaged $40 \%$ in the 21 dat treatment and 55\% in the 21 and 42 dat treatment. The implications of the development of cultural practices to manage lowland rice defoliating insects are discussed.
\end{abstract}

Keywords: Côte d'Ivoire, Oryza sativa L., compensation, defoliation, rice insect pests, West Africa

\section{Introduction}

A wide range of insects, belonging to several insect orders, feed on rice leaves. Among the major defoliators of lowland rice in West Africa are the beetles Chnootriba similis Thunberg and Trichispa sericea Guerin-Meneville; lepidopterous spp., the armyworms Spodoptera spp.; 
leaffolder Marasmia trapezalis Guenée; caseworm Nymphula stagnalis (Guenée); and a number of grasshopper spp., including Hieroglyphus africanus Uvarov, Oxya hyla Serville, and Zonocerus variegatus (L.) (Alam, 1992; Heinrichs and Barrion, 2002).

The total leaf area at flowering is closely related to rice grain production because the leaf area affects the amount of photosynthates available to the panicle (De Datta, 1981). Thus, defoliation can reduce rice yields significantly (Bowling, 1978). However, yield loss is highly dependent on the age of the plant when defoliation occurs, and plants can recover and compensate for defoliation damage, even resulting in yields higher than those of undamaged plants (Taylor, 1972). Rice crops have the capacity to compensate for stem-borer injury when it occurs at the vegetative stage (Rubia et al., 1996). Compensation is possible via production of new tillers (Akinsola, 1984; Viajante and Heinrichs, 1987) and by increasing the number of productive tillers (Luo, 1987) and grain weight (Akinsola, 1984; Luo, 1987).

Numerous studies have been conducted on various crops to determine the effect of pestsimulated defoliation on grain yield components. Artificial defoliation of rice was used to represent the feeding of the cutting-grass rat, Thryonomys swinderianus Tem., in Sierra Leone (Taylor, 1972). None, $50 \%$, and $66 \%$ of the leaves were removed at three plant growth stages: before tillering, during tillering, and after the tillering stage. Plants showed compensatory growth, resulting in increased tillering and yield, when defoliated during the tillering phase. However, yield decreased when defoliation occurred after the tillering stage (the early reproductive stage when panicle initiation occurs). Mallick and Ghosh Hajra (1977), in a study in India, found that $50 \%$ removal of rice leaves in the early and late vegetative stage reduced yields $1 \%$ and $35 \%$, respectively, while $100 \%$ defoliation at these same growth stages reduced yields $4 \%$ and $57 \%$, respectively. Yield decreases were attributed to a decrease in the number of grains and the weight of individual grains. In another study conducted in India, Anirudh Prasad and Prasad (1995) simulated leaffolder Cnaphalocrocis medinalis Guenée feeding. When plants were defoliated at 25 dat, there was an increase in the grain weight per plant at $25 \%$ and $50 \%$ defoliation and a $30 \%$ decrease in grain weight per plant at $75 \%$ defoliation. Defoliation at 50 dat decreased grain weight per plant by $37 \%$, $55 \%$, and $68 \%$ at $25 \%, 50 \%$, and $75 \%$ defoliation, respectively. The defoliation-caused grain weight loss was attributed to a decrease in the number of effective (productive or paniclebearing) tillers and to a decrease in the number of grains per plant. These studies indicate that the time (plant growth stage) and degree of defoliation are critical factors that determine the effect of defoliation on grain yield in rice.

When farmers observe insects defoliating their rice plants, they may resort to the application of insecticides. However, the cost of and environmental problems associated with insecticide applications may be avoided if the defoliation does not cause a loss in grain yield. In using IPM strategies in rice, the interaction of the ability of rice cultivars to compensate for defoliation, along with host plant resistance and other cultural practices, and the conservation of biological control agents, is considered a sustainable form of insect management. However, in lowland rice in West Africa, little is known about the relationship between the degree of defoliation at various plant growth stages, the ability to compensate for defoliation damage, and rice grain yield. Thus, the present study was conducted to generate information on the relationship between the degree of defoliation at 
various plant stages and the rice grain yield, which can be used as a guide in developing strategies for rice IPM programs.

\section{Materials and methods}

The study was conducted in a lowland area of the West Africa Rice Development Association (WARDA) M'bé Research Station near Bouaké, Côte d'Ivoire, during the wet seasons of 1994, 1995, and 1996. The station was in the transition zone between the humid forest and derived savanna. A popular high-yielding and short-duration (100-105 days) lowland rice cultivar, Bouaké 189, was used. It is grown throughout the inland valleys of West Africa. The area planted to Bouaké 189 in Côte d'Ivoire was 114,400 ha in 1990 (Becker and Diallo, 1992). Seedlings were transplanted at 21 days after sowing. One seedling was transplanted per hill at $25 \times 25 \mathrm{~cm}$ spacing between rows and between hills within a row. Plot

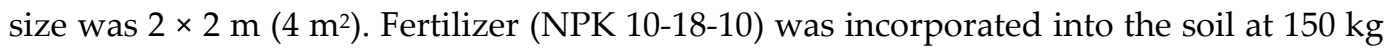
$\mathrm{ha}^{-1}$ at the time of transplantation. Urea $\left(45 \%, 75 \mathrm{~kg} \mathrm{ha}^{-1}\right)$ was broadcast at 30 and 60 days after transplanting (dat). The experiment was laid out in a randomized complete block design with four replications. The defoliation treatments tested were: $0 \%$ (control), $25 \%$ defoliation at 21 dat, $25 \%$ defoliation at 42 dat, 25\% defoliation at 21 and 42 dat, $50 \%$ defoliation at 21 dat, $50 \%$ defoliation at 42 dat, $75 \%$ defoliation at 21 dat, $75 \%$ defoliation at 42 dat, $75 \%$ defoliation at 21 and 42 dat, 100\% defoliation at 42 dat, and $100 \%$ defoliation at 21 and 42 dat. The percentage natural defoliation due to insects was monitored on all plots.

Twenty plants, in $1.25 \% \mathrm{~m}^{2}$ in the center of each plot, were defoliated. Leaves on each plant were cut with scissors to produce the various treatments. To avoid transmission of rice yellow mottle virus (RYMV), which is prevalent in the area, the scissors was dipped in $20 \%$ alcohol and then into sterilized water after each plant was cut.

To determine the grain yield of the various treatments, the total grain from 20 plants of each replicate was harvested, weighed, and corrected for $14 \%$ moisture. To identify the effect of defoliation on the attributes contributing to grain yield, tiller height, the total number of tillers per plot, the number of tillers with panicles, and the weight of 100 grains were recorded for the 20 plants in each replicate. Statistical analyses were conducted as based on the 20 plants consisting of each replicate. Each attribute was tested by ANOVA, and means were separated by the LSD test $(p<0.05)$.

\section{Results}

\subsection{Tiller height}

Natural defoliation due to insects was $55 \%$ in all plots and was not considered a factor affecting the results. Simulated insect defoliation reduced tiller height (figure 1, A-C). In 1994 (figure 1, A), only the 75\% defoliation at 42 dat and the $100 \%$ defoliations at 21 and at 21 and 42 dat significantly reduced tiller height. Mean height in the control was $90 \mathrm{~cm}$, while it was $79 \mathrm{~cm}$ in the latter two treatments. In 1995, significant decreases in tiller height occurred in the $50 \%$ at 42 dat and in the two $100 \%$ defoliation treatments (figure 1, B). Results in 1996 (figure 1, C) were similar to those in 1994 (figure 1, A), where the 75\% 
defoliation at 42 dat and the two $100 \%$ defoliation treatments significantly reduced tiller height.
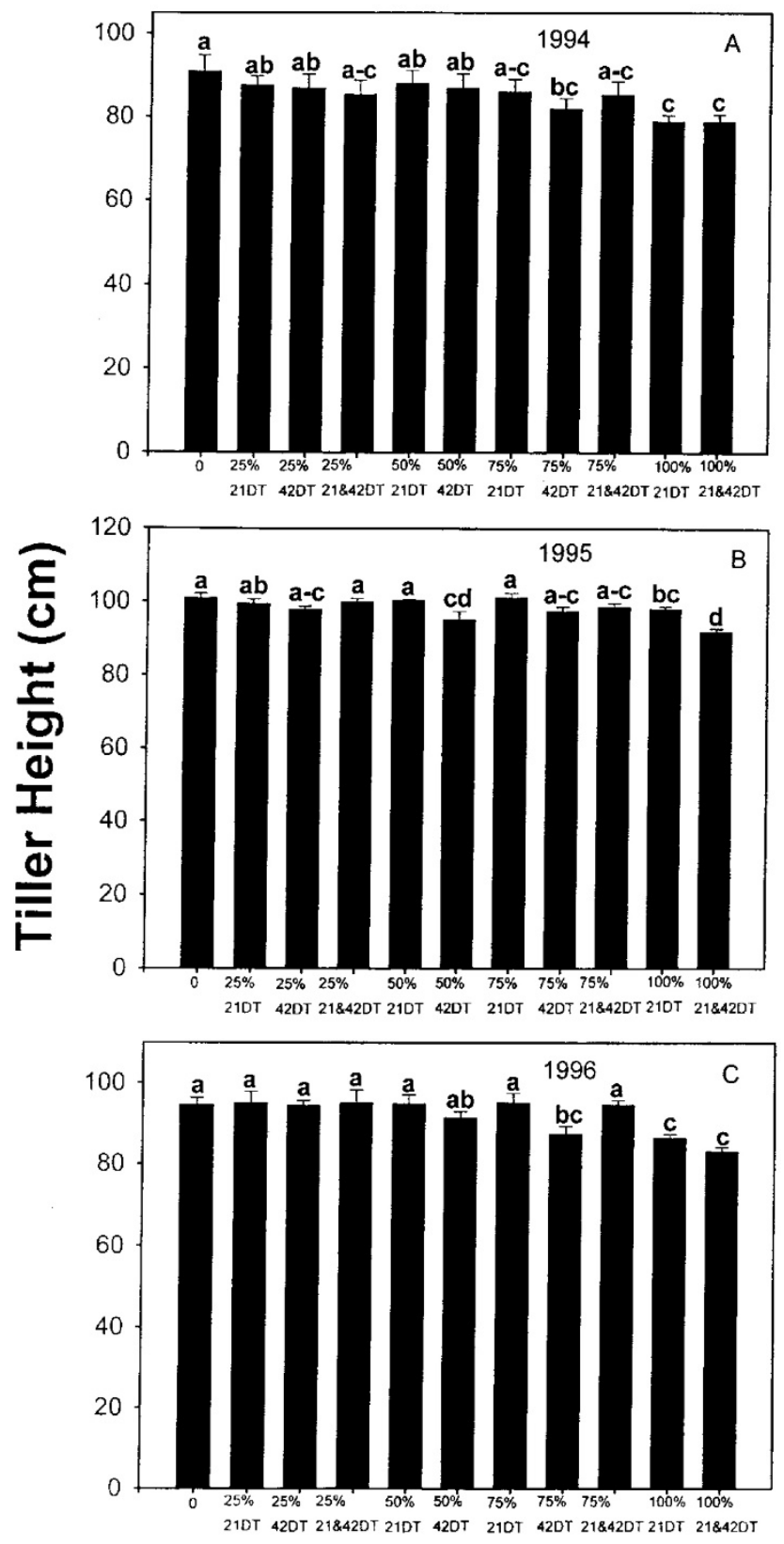

Percent Defoliation

Figure 1. Effect of artificial defoliation on the height $(\mathrm{cm})$ of tillers of rice variety Bouaké 189. Mean separation with the least significant difference test (LSD) $(p=0.05)$. Heights in 1994 (A), 1995 (B), and 1996 (C). WARDA M’bé Research Station, Bouaké, Côte d'Ivoire. 


\subsection{Total number of tillers}

The total number of tillers was significantly affected by defoliation in all 3 years (figure 2, A-C). Tiller number was most severely reduced in the $100 \%$ defoliation at 21 and 42 dat treatments. The $100 \%$ defoliation at the 21 and 42 dat treatment reduced tiller number by $46 \%, 29 \%$, and $48 \%$ in 1994,1995 , and 1996 , respectively.

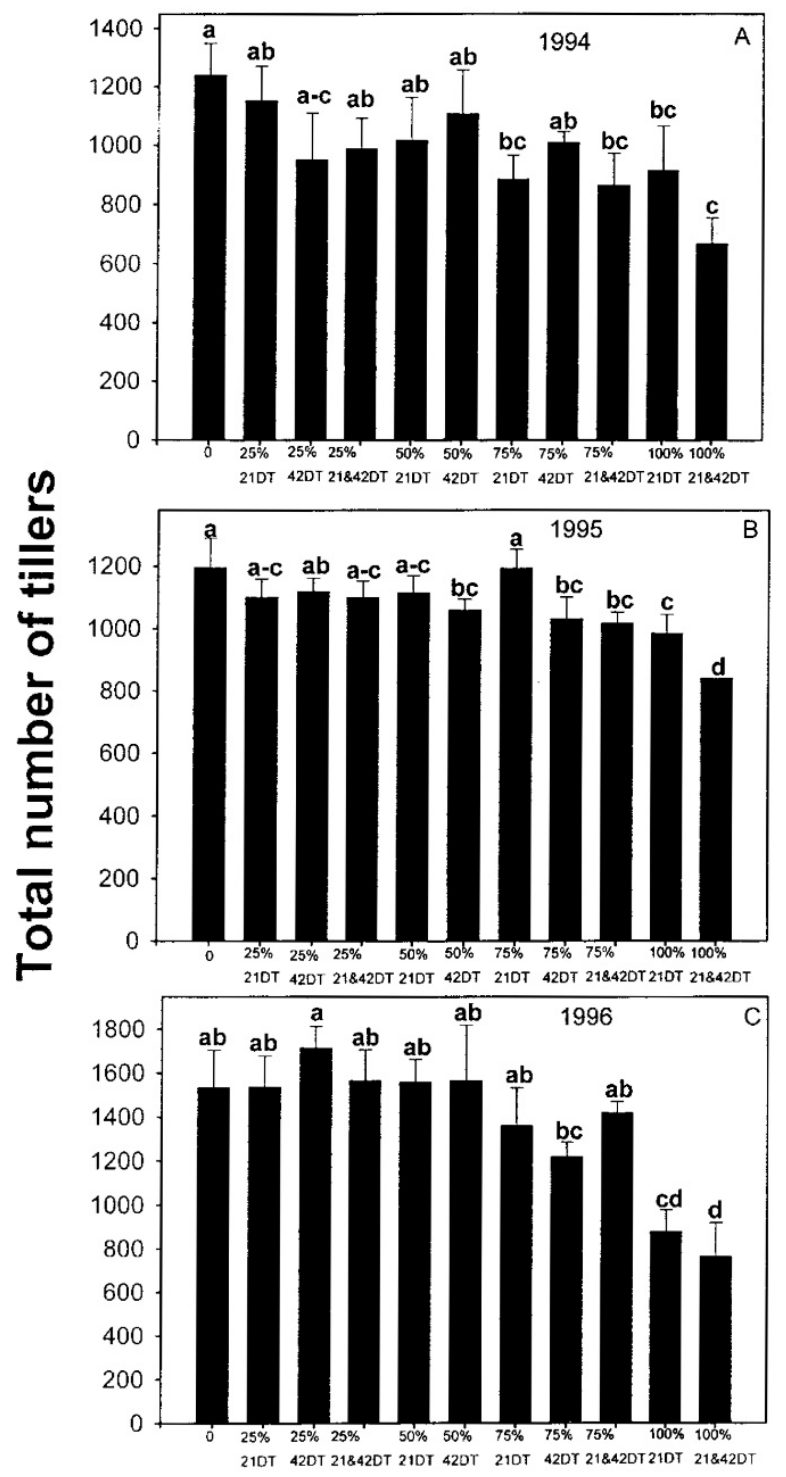

\section{Percent Defoliation}

Figure 2. Effect of artificial defoliation on the total number of tillers per 20 plants of rice variety Bouaké 189 . Mean separation with the least significant difference test (LSD) $(p=$ 0.05). Tiller numbers in 1994 (A), 1995 (B), and 1996 (C). WARDA M’bé Research Station, Bouaké, Côte d'Ivoire. 


\subsection{Percent effective tillers}

The percent effective (panicle-bearing) tillers was not affected by defoliation (figure 3, AC). Although differences in treatments were slight, in 1994 (figure 3, A), the percent effective tillers was significantly least in the control.
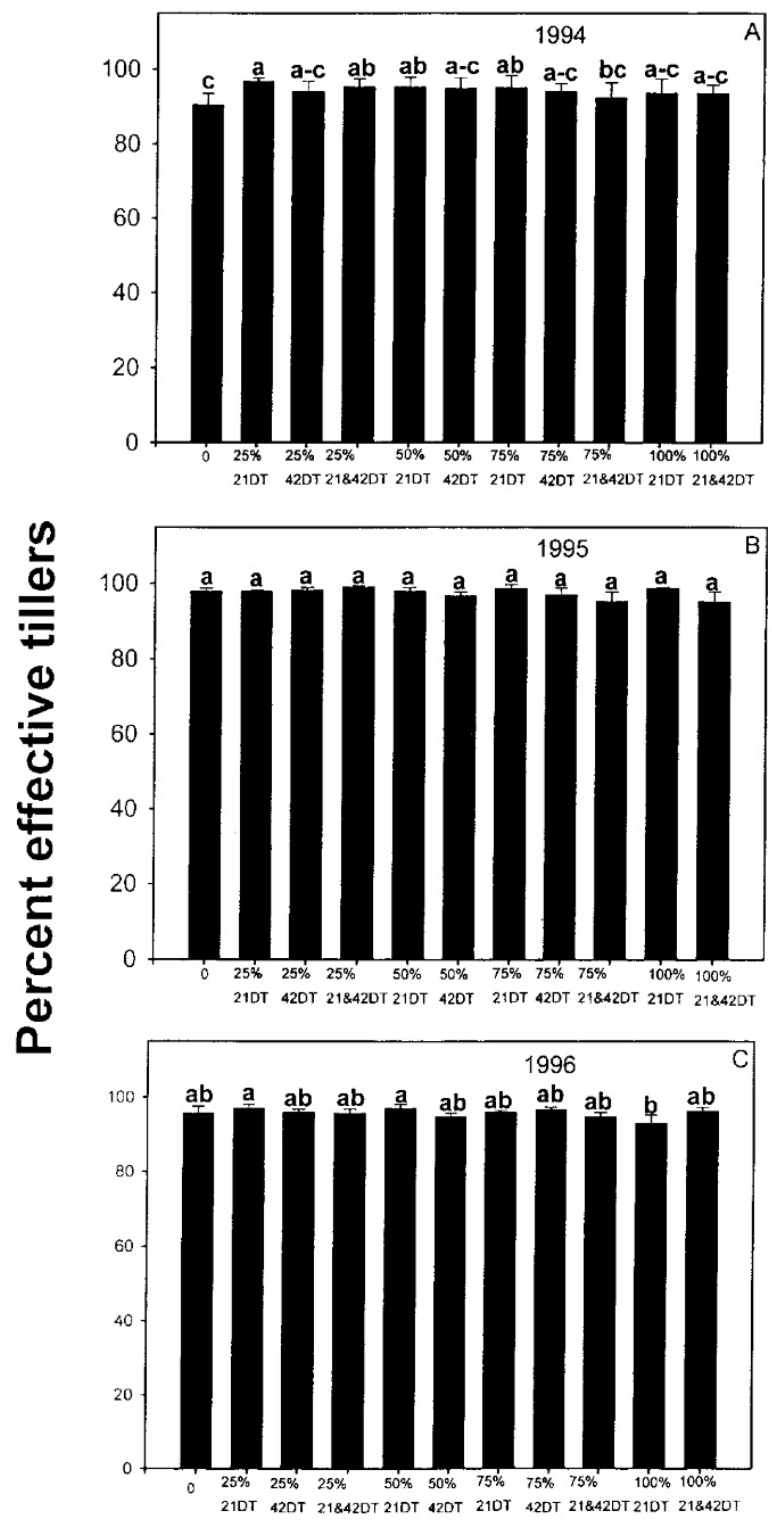

\section{Percent Defoliation}

Figure 3. Effect of percent artificial defoliation on the percent effective tillers of rice variety Bouaké 189. Mean separation with the least significant difference test (LSD) $(p=0.05)$. Percent effective tillers in 1994 (A), 1995 (B), and 1996 (C). WARDA M’bé Research Station, Bouaké, Côte d'Ivoire. 


\subsection{Weight of 100 grains}

There was no trend in the relation to the effect of defoliation on the weight of grains (figure 4, A-C). The mean weight of 100 grains over all treatments in 1994, 1995, and 1996 was about $4.5,3.0$, and $2.8 \mathrm{~g}$, respectively. The only significantly low weight treatments were the three $75 \%$ treatments in 1994 and the $50 \%$ at 42 dat treatment in 1996 . However, these treatments were not significantly different from the control.

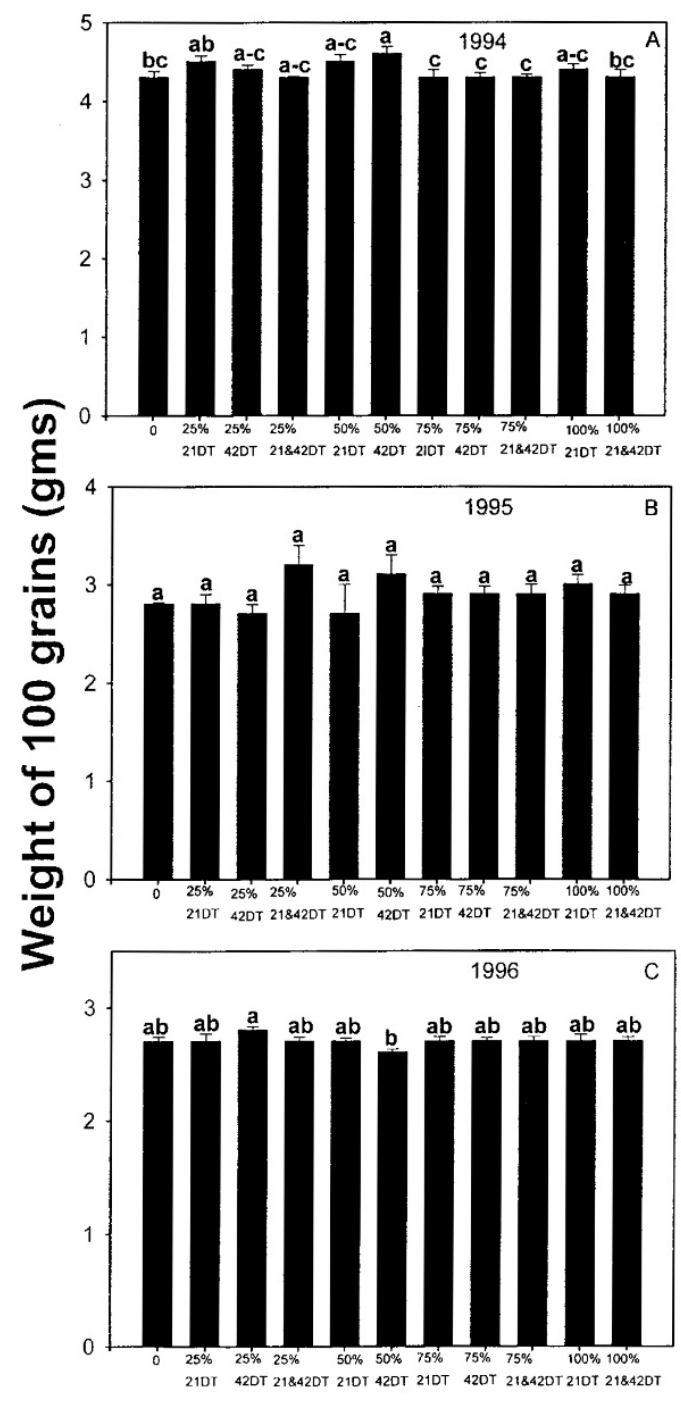

\section{Percent Defoliation}

Figure 4. Effect of percent artificial defoliation on weight of 100 grains $(\mathrm{g})$ of rice variety Bouaké 189. Mean separation with the least significant difference test (LSD) $(p=0.05)$. Weight of 100 grains in 1994 (A), 1995 (B), and 1996 (C). WARDA M'bé Research Station, Bouaké, Côte d'Ivoire. 


\subsection{Grain yields}

Grain yields were affected by defoliation and there were significant differences between treatments $(p<0.01)$ in all 3 years of the study (tables 1-3 and figure 5, A-C). In 1994, only the $75 \%$ at $21 / 42$ dat and the $100 \%$ defoliation at 21 dat and $100 \%$ at $21 / 42$ dat treatments were significantly lower than the control (figure 5, A). On average, grain yields in these treatments were reduced $33 \%, 36 \%$, and $65 \%$, respectively.

Table 1. Analysis of variance indicating the source of variation, the degrees of freedom (d.f.), the mean squares, and the probability with F-test $(P>F)$ for rice grain yields $\left(\mathrm{kg} \mathrm{ha}^{-1}\right), 1994$

\begin{tabular}{lrcc}
\hline Source of variation & d.f. & MS & P $>$ F \\
\hline Replication & 3 & $209,568.02$ & 0.3431 \\
Treatments & 10 & $3,460,195.5$ & 0.0001 \\
Error & 43 & $181,442.7$ & \\
\hline
\end{tabular}

MS, mean squares (from type III sum of squares)

Table 2. Analysis of variance indicating the source of variation, the degrees of freedom (d.f.), the mean squares, and the probability with F-test $(P>F)$ for rice grain yields $\left(\mathrm{kg} \mathrm{ha}^{-1}\right), 1995$

\begin{tabular}{lrcc}
\hline Source of variation & d.f. & MS & $P>F$ \\
\hline Replication & 3 & $139,796.80$ & 0.38 \\
Treatments & 10 & $490,222.5$ & 0.0026 \\
Error & 43 & $9,260,679.5$ & \\
\hline
\end{tabular}

MS, mean squares (from type III sum of squares)

Table 3. Analysis of variance indicating the source of variation, the degrees of freedom (d.f.), the mean squares, and the probability with F-test $(P>F)$ for rice grain yields $\left(\mathrm{kg} \mathrm{ha}^{-1}\right), 1996$

\begin{tabular}{lrrr}
\hline Source of variation & d.f. & MS & $P>F$ \\
\hline Replication & 3 & $17,643,544.4$ & 0.0001 \\
Treatments & 10 & $5,615,019.5$ & 0.0016 \\
Error & 43 & $45,185,897.1$ & \\
\hline
\end{tabular}

MS, mean squares (from type III sum of squares) 

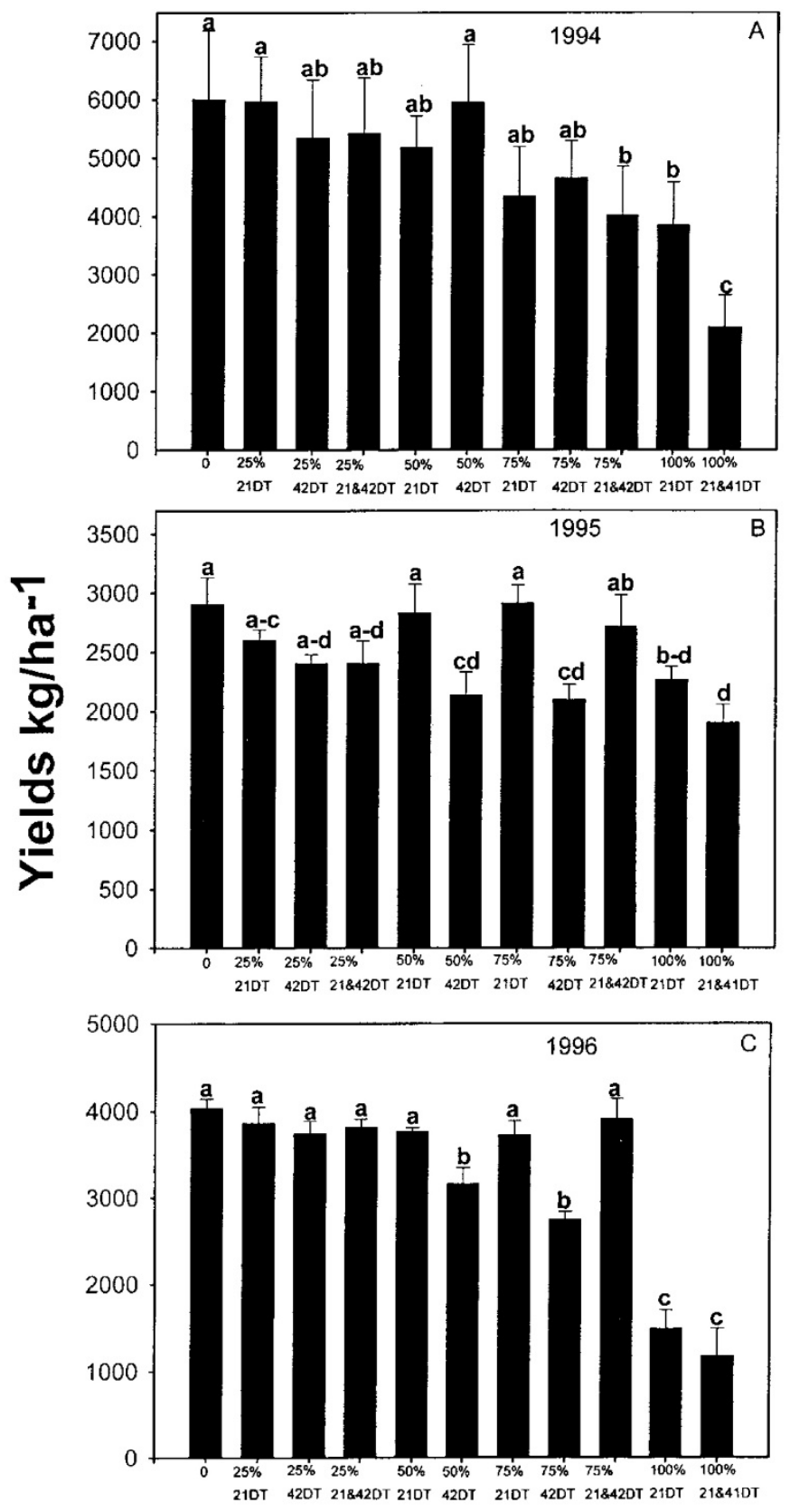

\section{Percent Defoliation}

Figure 5. Effect of percent artificial defoliation on the grain yield in $\mathrm{kg} \mathrm{ha}^{-1}$ of plots of rice variety Bouaké 189. Mean separation with the least significant difference test (LSD) $(p=$ 0.05). Grain yield in 1994 (A), 1995 (B), and 1996 (C). WARDA M’bé, Research Station, Bouaké, Côte d'Ivoire. 
In 1995 , the $50 \%$ at 42 dat, $75 \%$ at 42 dat, $100 \%$ at 21 dat, and $100 \%$ at $21 / 42$ dat treatments significantly decreased grain yield below that of the control (figure 5, B).

The mean percent decreases for these treatments were $27,28,22$, and 35 , respectively.

Although grain yield in the control and grain yield decreases at the $100 \%$ defoliation levels in 1996 (figure 5, C) were greater than those in 1995 (figure 5, B), the trend of the percent yield decrease due to defoliation was similar to that of 1995 . The $50 \%$ at 42 dat, $75 \%$ at 42 dat, $100 \%$ at 21 dat, and $100 \%$ at $21 / 42$ dat treatments significantly decreased grain yield below that of the control (figure 5, B). The mean percent decreases for these treatments were $22,32,63$, and 71 , respectively.

\section{Discussion and conclusions}

Artificial defoliation of rice cultivar Bouake 189 in the vegetative growth stage reduced grain yields. The mean percent yield decrease over the 3 years for the $100 \%$ defoliation at 21 dat and the $100 \%$ defoliation at $21 / 42$ dat treatments was $40 \%$ and $55 \%$, respectively. Yield decrease was in part due to the decrease in the number of tillers produced. Tiller number, in turn, determined the number of panicle-bearing tillers at harvest time. The trend in tiller number, in relation to the percent defoliation and number of defoliations, was similar to that for grain yield, especially in 1994 and 1995 (figure 5).

The percentage of effective tillers was not affected by defoliation. This is believed to be because defoliation occurred before the panicle initiation stage of growth. Defoliation at the reproductive stage, after panicle initiation had occurred, caused greater yield loss than defoliation in the vegetative stage (Mallick and Hajra, 1977). Plants defoliated in the vegetative stage have more time to recover and replace lost tillers and foliage before grain development. At the grain development stage, the amount of foliage is critical for the assimilate accumulation in the panicle and for subsequent grain production (Mallick and Hajra, 1977).

The time of recovery to replace tillers and foliage lost due to defoliation is partially dependent on the growth duration of the cultivar. Long- and short-duration cultivars have similar durations of the reproductive phase of growth, but they differ in the length of their vegetative phase (De Datta, 1981). The rice cultivar used here, Bouaké 189, is a short-duration cultivar. Similar treatments as imposed here would be expected to have a more severe effect on the yield of a very short-duration (about 80 days) cultivar and a lesser effect on a longduration (about 150 days) cultivar.

Grain yields in the control differed over the 3 years of the study. Yields in 1994, 1995, and 1996 were about 6,000, 3,000, and 4,000 $\mathrm{kg} \mathrm{ha}^{-1}$ respectively. Differences in grain yields between years were assumed to be mostly due to differing environmental conditions. Yields in 1995 were the lowest, as were the percent yield losses due to defoliation (figure 5). Although percentage yield losses in the 100\% 21/42 dat treatments were similar in 1994 and 1996, the economic losses were much greater in the 1994 study because of a 2,000 kg greater yield that year.

Although two 100\% defoliations (21/42 dat), as expected, caused greater yield losses than one defoliation ( 21 dat) during all years, the results at the $75 \%$ defoliation level were inconsistent in 1995 and 1996 (figure 5, B-C). In 1995 and 1996, the 21/42 dat treatments 
unexpectedly had higher yields than the 42 dat treatments. In 1996, bird attack on the panicles was observed on one of the replications of the $75 \%$ at $21 / 42$ dat treatments, but a probable cause for the lower yield in 1995 was not known. Also undetermined was the possible relationship between the effect of defoliation in the treatment of $75 \%$ at $21 / 42$ dat and the extent of the bird attack.

It is difficult to simulate the exact nature of the damage caused by defoliating insects. Artificial defoliation using scissors to clip the foliage may not be the same as actual feeding patterns by insects (Rice et al., 1982). For example, beetle feeding may result in scraping or holes in the leaves, leaffolders scrape the green portion of the leaf from within folded leaves, and armyworms and grasshoppers remove irregular portions of the leaves but may leave the midvein intact. In the artificial defoliation procedure used in this and most other studies, all of the leaf tissue is removed at once, whereas in insect feeding, damage occurs over longer periods. Instantaneous artificial defoliation may not have the same effect as an irregular, prolonged defoliation (Rice et al., 1982). However, in spite of the difficulty of exactly simulating natural defoliation by insects, leaf clipping is considered a useful method to simulate natural defoliation, and it has been used for many crops by numerous authors, including those cited in the references.

Based on the present results, it is evident that unless defoliation is $450 \%$, insecticide applications on Bouaké 189 in lowland ecosystems are unnecessary when the defoliation occurs at the vegetative stage. This is apparently due to the ability of rice plants to compensate for foliage removal.

Rubia et al. (1996) studied the mechanisms of compensation of rice plants to yellow stem borer, Scirpophaga incertulas (Walker), injury. Compensation mechanisms included increased tillering, an increased percentage of effective tillers, and an increased grain weight of damaged plants. There was also an increase in the photosynthesis rate of green leaves on stem borer-injured tillers. Assimilates were transferred from injured tillers to healthy tillers. The translocation was more effective at the vegetative stage than at the reproductive stage, as based on ${ }^{14} \mathrm{C}$ activity. Thus, the earlier in the plant growth stage the injury occurs, the more rapidly the plants can compensate by translocating assimilates from injured to healthy tillers.

Rubia et al. (1996) cited studies by Wareing et al. (1968), Meidner et al. (1970), and Daley and McNeil (1987) in suggesting two reasons for compensation. First, because partial defoliation can cause increased photosynthesis in the remaining leaves, it allows an improved supply of cytokinins to the remaining leaves by removal of sinks, and leads to an increase in carboxylation enzymes. Second, an increase in the assimilate demand by previously existing or new sinks (e.g., replacement tissue) can increase photosynthesis in the remaining leaves.

In the development of a lowland rice IPM strategy for West African farmers, the compensation of rice plants to defoliation must be take into consideration in the development of insect management strategies. Insect-caused defoliation of $450 \%$ in the vegetative stage only occasionally occurs in lowland rice in West Africa. Thus, farmer training in rice IPM should emphasize the regular monitoring of fields and nonintervention with insecticides until needed. This approach will allow the beneficials to maintain insect pest populations and insect-induced damage below the action thresholds. To prevent yield losses, when 
defoliators do reach high population levels, there is a need to breed rice cultivars and identify fertilizer management practices that promote plant compensation to defoliation damage. One approach is to select cultivars with enhanced mechanisms of plant compensation to defoliator injury. This may be done during the stage of rice-breeding line evaluations by selecting cultivars that show increased photosynthesis of green, undamaged leaves in response to insect injury on adjacent leaves, and incorporating this and other characters such as a high tillering ability into high-yielding cultivars. In addition, tillering is strongly influenced by nitrogen supply (De Datta, 1981), thus plant recovery to defoliation may be enhanced by fertilizer application.

\section{References}

Akinsola, E. A., 1984. Effect of rice stem borer infestation on grain and yield components. Insect Science and Its Application, 5, 91-94.

Alam, M. S., 1992. A survey of rice pests in Nigeria. Tropical Pest Management, 38, 115-118.

Anirudhprasad, P., and Prasad, D.,1995. Effect of simulated leaf damage on yield attributes of rice. Indian Journal of Entomology, 57, 378-384.

Becker, L., and Diallo, R. 1992. Caracterisation et classification des ecosystemes rizicoles de la Côte d'Ivoire (Bouaké: ADRAO).

Bowling, C. C., 1978. Simulated insect damage to rice: effects of leaf removal. Journal of Economic Entomology, 71, 377-378.

Daley, P. F., and McNeil, J. N., 1987. Canopy photosynthesis and dry matter partitioning of alfalfa blotch leafminer Agromyza frontella (Rondani). Canadian Journal of Plant Science, 67, 433-443.

De Datta, S. K., 1981. Principles and Practices of Rice Production (New York: Wiley).

Heinrichs, E. A., and Barrion, A. T., 2002. Biology and Ecology of Rice-Feeding Insects of West Africa (Los Baños: International Rice Research Institute) (in press).

Luo, S. F., 1987. Studies on the compensation of rice to the larval damage caused by the Asian rice borer (Chilo suppressalis (Walker)). Scientia Agricultura Sinica, 20, 67-72.

Mallick, E. H., and Ghosh Hajra, N., 1977. Response of rice plant to defoliation treatments at different developmental stages. Indian Agriculturist, 21, 51-56.

Meidner, H., 1970. Effects of photoperiodic induction and debudding in Xanthium pennsylvanicum and of partial defoliation in Phaseolus vulgaris on rates of net photosynthesis and stomatal conductances. Journal of Experimental Botany, 21, 164-169.

Rice, S. E., Grigarick, A. A., and Way, M. O., 1982. Effect of leaf and panicle feeding by armyworm (Lepidoptera: Noctuidae) larvae on rice grain yield. Journal of Economic Entomology, 75, 593-595.

Rubia, E. G, Heong, K. L., Zaluck, M., Gonzales, B., and Norton, G. A., 1996. Mechanisms of compensation of rice plants to yellow stem borer Scirpophaga incertulas (Walker) injury. Crop Protection, $15,335-340$.

Viajante, V., and Heinrichs, E. A., 1987. Plant age effect of rice cultivar IR46 on susceptibility to the yellow stem borer Scirpophaga incertulas (Walker) (Lepidoptera: Pyralidae). Crop Protection, 6, 33-37.

Wareing, P. F., Khalifa, M. M., and Treharne, K. J., 1968. Rate-limiting processes in photosynthesis at saturating light intensities. Nature, 220, 453-457. 